\title{
EFFECT OF PHENYLHYDRAZINE DERIVATIVES IN THE TREATMENT OF POLYCYTHEMIA
}

\author{
BY PERRIN H. LONG
}

(From the Thorndike Memorial Laboratory, Boston City Hospital, Boston, Massachusetts)

(Received for publication January 22, 1926)

The use of phenylhydrazine derivatives as therapeutic agents was introduced soon after the discovery of acetyl phenylhydrazine (pyrodin) by Liebreich. It was employed as an antipyretic. Renvers (1), in discussing this drug, pointed out that while its action as an antipyretic was fairly efficient, its toxic action upon the red blood cells made its use dangerous. He describes a case of rheumatic fever in which pyrodin grams 0.5 was given for three days, following which the red blood cell count dropped to two million eight hundred thousand cells. A distinct icterus developed and at the same time the urine became burgundy colored and contained much urobilin. A series of similar ill effects was noted by other observers who used the phenylhydrazine derivatives as antipyretics. For many years these drugs were employed only in the production of experimental anemias in animals and it was not until 1908 that Morawitz and Pratt (2) suggested that phenylhydrazine hydrochloride should be given a trial in polycythemia.

Sometime later Eppinger and Kloss (3) reported that they had obtained satisfactory results with this drug, using at first $10 \mathrm{cc}$. of a 5 per cent solution injected subcutaneously in a case of polycythemia. Further observation convinced them that oral administration was as effective as subcutaneous injection. A reduction of the red blood cells and hemoglobin with an occasional leukocytosis was noted.

Taschenberg (4) also used the drug in polycythemia with a satisfactory decrease of the red blood cells and a fall in the percent of hemoglobin to normal limits. His observations led him to believe that a specific resistance to phenylhydrazine was developed by the red cells which necessitated the administration of increasingly large doses to bring about the desired results. 
The untoward effects of the therapy were pointed out by Strassburger (5) who treated two cases of polycythemia with phenylhydrazine hydrochloride. In his first case, as a result of too intensive treatment, the red count dropped to 2,600,000, with a hemoglobin of 64 per cent, and the patient felt very weak at this period. His second case, treated with smaller amounts was greatly benefited by the therapy. Geisbock (6) described a patient suffering from polycythemia hypertonica with a systolic blood pressure of $180 \mathrm{~mm}$. of mercury. Under treatment with phenylhydrazine hydrochloride the patient's red blood count was reduced to normal and the systolic pressure lowered to $120 \mathrm{~mm}$.

At the Johns Hopkins Clinic, Owen (7) treated one case with excellent results. The red blood cells and hemoglobin reached a point somewhat below normal, with a simultaneous relief of the subjective symptoms. After three months, however, there was a recurrence of symptoms and the patient returned for further treatment. The second course of treatment showed that with the original dosage the red blood count could again be controlled as in the first course of treatment. Levi (8) believed that cirrhosis of the liver is accentuated by blood destruction and he advised against the use of phenlyhdrazine in patients suffering from polycythemia.

In the Thorndike Memorial Laboratory, phenylhydrazine derivatives have been administered to three patients with polycythemia and one patient with hypertension. The observations here reported are the results of a study of the therapeutic dosage, the mode of action of the drug and the benefits derived therefrom. It is recognized that the series is not sufficiently large to warrant general conclusions, but certain actions of the drug seem very constant and are illustrated in the case reports that follow.

Case I. F. S. A Jewish housewife, aged 68, entered the hospital August 24, complaining of pains in the arms, legs and chest. Her past and family history were unimportant. The skin of the patient's face and hands had been a dusky red color for eighteen years. In 1918 she began to have pains in her long bones and at that time a diagnosis of polycythemia vera was made. She had $\mathrm{x}$-ray and radium therapy over her long bones with no improvement in her condition. The pain had steadily increased until the time of entry into the hospital.

The physical examination showed a poorly nourished and poorly developed woman who was complaining bitterly. The skin of the entire body, and especially 
that of the hands and feet, had a dusky red tint. Numerous spider angiomata occurred in the skin of the face. The conjunctivae were moderately injected. The mucous membranes of the mouth were a slaty blue color. Her tongue was not atrophic. The heart and lungs were normal. A moderate smooth peripheral arterio-sclerosis was present. Blood pressure-130/70. The spleen was not felt.

TABLE 1

\begin{tabular}{|c|c|c|c|c|c|c|}
\hline Date & $\begin{array}{l}\text { Hemo- } \\
\text { globin }\end{array}$ & $\begin{array}{c}\text { Red } \\
\text { blood cells }\end{array}$ & $\begin{array}{c}\text { White } \\
\text { blood cells }\end{array}$ & $\begin{array}{c}\text { Reticulated } \\
\text { cells }\end{array}$ & $\underset{\text { bilirubir }}{\text { Plasma }}$ & Drug \\
\hline & per cent & millions & thousands & per cent & mgm. & grams \\
\hline August $19 \ldots \ldots \ldots \ldots \ldots$ & 135 & 10.0 & 5.0 & & 0.4 & \\
\hline August $21 \ldots \ldots \ldots \ldots \ldots$ & \multicolumn{3}{|c|}{ (Venesection $500 \mathrm{cc}$. ) } & & 0.44 & \\
\hline August $25 \ldots \ldots \ldots \ldots \ldots$ & 139 & 8.3 & & 0.2 & & \\
\hline August $27 \ldots \ldots \ldots \ldots \ldots$ & (Venes & ection 500 & cc.) & & & \\
\hline August $27 \ldots \ldots \ldots \ldots \ldots$ & 133 & 8.4 & & & & \\
\hline September $2 \ldots \ldots \ldots \ldots \ldots$ & 135 & 8.5 & & & & \\
\hline September $10 \ldots \ldots \ldots \ldots \ldots$ & 133 & 8.2 & & & & \\
\hline September $16 \ldots \ldots \ldots \ldots \ldots$ & 125 & 7.3 & 4.2 & 0.3 & 0.44 & \\
\hline September $16 \ldots \ldots \ldots \ldots \ldots$ & & & & & & 0.1 \\
\hline September $17 \ldots \ldots \ldots \ldots \ldots$ & 126 & 7.3 & 5.6 & & & 0.1 \\
\hline September $18 \ldots \ldots \ldots \ldots \ldots$ & 131 & 7.3 & 6.7 & & & 0.1 \\
\hline September $19 . . . \ldots \ldots$. & 121 & 6.6 & 6.5 & & & 0.1 \\
\hline September $20 \ldots \ldots \ldots \ldots \ldots$ & 115 & 6.4 & 5.6 & & & 0.1 \\
\hline September $21 \ldots \ldots \ldots \ldots \ldots$ & 112 & 6.6 & 5.6 & & & \\
\hline September $22 \ldots \ldots \ldots \ldots$ & 112 & 6.5 & 6.8 & 1.3 & 1.0 & 0.1 \\
\hline September $23 . . \ldots \ldots \ldots$ & 108 & 6.4 & 7.9 & & & 0.1 \\
\hline September $24 . \ldots \ldots \ldots$. & 105 & 6.0 & 9.6 & & & 0.1 \\
\hline September $25 \ldots \ldots \ldots \ldots \ldots$ & 99 & 5.9 & 6.1 & & & 0.1 \\
\hline September $26 \ldots \ldots \ldots \ldots \ldots$ & 92 & 5.4 & 6.8 & & & \\
\hline September $27 \ldots \ldots \ldots \ldots \ldots$ & 93 & 5.6 & 6.9 & & & \\
\hline September $28 \ldots \ldots \ldots \ldots$ & & & & & & 0.1 \\
\hline September $28 \ldots \ldots \ldots \ldots \ldots$ & 93 & 6.0 & 8.0 & & & 0.1 \\
\hline September $29 . \ldots \ldots \ldots$ & 91 & 4.6 & 7.4 & & 0.8 & 0.1 \\
\hline September $30 \ldots$ & 90 & 5.3 & 6.0 & 2.1 & & \\
\hline October $1 \ldots .$. & 82 & 4.8 & 10.3 & & & \\
\hline October $2 \ldots \ldots$ & 72 & 5.4 & 8.6 & & & \\
\hline October $3 \ldots \ldots \ldots$ & 76 & 5.5 & 8.8 & & & \\
\hline October $4 \ldots \ldots \ldots \ldots$. & 74 & 4.0 & 6.8 & & & \\
\hline October $5 \ldots \ldots \ldots \ldots \ldots$ & 71 & 4.2 & 6.9 & & & \\
\hline October $6 \ldots \ldots \ldots \ldots \ldots$ & 76 & 4.6 & 6.1 & 3.7 & 0.9 & \\
\hline
\end{tabular}

Laboratory data. Red blood cells-8,360,000. Hemoglobin (NewcomerHaldane)-139 per cent. White blood cells-5,000. The smear showed slight achromia. Reticulated red blood cells -0.2 per cent. Hematocrit -62 per cent. Blood bilirubin (Van den Bergh) $-0.4 \mathrm{mgm}$. per $100 \mathrm{cc}$. of plasma with a delayed direct diazo reaction. The blood Wassermann was negative. The gastric 
contents showed free hydrochloric acid. The urine and stool were normal. Basal metabolism (Aub-Dubois) -+12 per cent. Diagnosis: Polycythemia vera.

As a preliminary measure the patient received two venesections during which a liter of blood was removed, but the red blood cell count and hemoglobin were not affected. Three weeks after the last venesection, treatment with phenylhydrazine hydrochloride in doses of 0.1 gram per day was started.

As will be noted in table 1, there was a rapid decrease in the hemoglobin content of the blood and in the total number of red blood cells. The changes in the subjective symptoms of the patient did not parallel the blood picture, and it was not until several days after the drug was discontinued that the pains in the long bones and thorax disappeared. The urine, which before the administration of the drug had been a light straw color, became a dark amber color soon after the treatment was instituted. A moderate reduction of Benedict's Solution was noted on the first day and urobilin made its appearance on the third day. There was no albuminuria or hematuria at any time.

The patient was discharged greatly improved with instructions to return for further observations in a month's time. Nothing more was heard of her until May, 1925, when she entered the hospital complaining of pain in the long bones and epigastrium. After leaving the hospital in October, 1924, she remained in good health for three months, when a recurrence of symptoms became evident. She obtained phenylhydrazine hydrochloride capsules from the outpatient department of another hospital, and instead of following the instructions given there took seven capsules in as many days. Very little relief was obtained, however, and the pain so steadily increased that she decided to re-enter this hospital for treatment.

At the time of the second entry the physical examination had not changed. The red blood cells numbered ten million. Hemoglobin (Newcomer-Haldane)130 per cent. White blood cells-9,800. The smear showed a slight achromia. Reticulated red blood cells- 0.1 per cent. Hematocrit-58.5 per cent. Blood bilirubin (Van den Bergh) $-0.5 \mathrm{mgm}$. per $100 \mathrm{cc}$. of plasma with a delayed direct diazo reaction. The blood Wassermann was negative. The gastric contents showed free hydrochloric acid. The urine and stool were normal. 
TABLE 2

\begin{tabular}{|c|c|c|c|c|c|c|}
\hline Date & $\begin{array}{l}\text { Hemo- } \\
\text { globin }\end{array}$ & $\begin{array}{c}\text { Red } \\
\text { blood cells }\end{array}$ & $\begin{array}{l}\text { White } \\
\text { blood cells }\end{array}$ & $\begin{array}{c}\text { Reticulated } \\
\text { red cells }\end{array}$ & $\begin{array}{c}\text { Plasma } \\
\text { bilirubin }\end{array}$ & Drug \\
\hline & per cent & millions & thousands & per cont & mgm. & grams \\
\hline May $18 \ldots \ldots \ldots \ldots \ldots \ldots$ & 130 & 9.3 & 7.8 & 0.2 & & \\
\hline May $20 \ldots \ldots \ldots \ldots \ldots$ & 140 & 8.8 & 12.1 & & & \\
\hline May $21 \ldots \ldots \ldots \ldots \ldots$ & 139 & 9.4 & 12.1 & & & \\
\hline May $22 \ldots \ldots \ldots \ldots \ldots \ldots$ & & & & 0.8 & 0.5 & 0.1 \\
\hline May $23 \ldots \ldots \ldots \ldots \ldots$ & 140 & 8.9 & 9.4 & & & 0.1 \\
\hline May $21 \ldots \ldots \ldots \ldots \ldots$ & 145 & 9.6 & 7.9 & & & 0.1 \\
\hline May $25 \ldots \ldots \ldots \ldots \ldots \ldots$ & 135 & 11.1 & 10.8 & & & 0.1 \\
\hline May $26 \ldots \ldots \ldots \ldots \ldots$ & 125 & 8.4 & 11.9 & 19.0 & 0.6 & 0.1 \\
\hline May $27 \ldots \ldots \ldots \ldots \ldots \ldots$ & 125 & 8.4 & 10.6 & & & 0.1 \\
\hline May $28 \ldots \ldots \ldots \ldots \ldots \ldots$ & 135 & 7.4 & 7.5 & & & 0.2 \\
\hline May $29 \ldots \ldots \ldots \ldots \ldots \ldots$ & 130 & 9.8 & 11.2 & & & 0.2 \\
\hline June $1 \ldots \ldots \ldots \ldots \ldots \ldots$ & 125 & 7.9 & 11.5 & & & 0.2 \\
\hline June $2 \ldots \ldots \ldots \ldots \ldots$ & 125 & 7.4 & 11.9 & & & 0.2 \\
\hline June $3 \ldots \ldots \ldots \ldots \ldots$ & 109 & 6.4 & 9.6 & 39.0 & $1: 4$ & 0.2 \\
\hline June $4 \ldots \ldots \ldots \ldots \ldots \ldots$ & 109 & 6.4 & 9.0 & & & 0.2 \\
\hline June $6 \ldots \ldots \ldots \ldots \ldots$ & 101 & 6.5 & 12.2 & & & \\
\hline June $7 \ldots \ldots \ldots \ldots \ldots$ & 98 & 5.6 & 18.0 & & & \\
\hline June $8 \ldots \ldots \ldots \ldots \ldots$ & 98 & 5.9 & 15.6 & & & \\
\hline June $10 \ldots \ldots \ldots \ldots \ldots$ & 62 & 3.8 & 16.1 & & 3.6 & \\
\hline June $11 \ldots \ldots \ldots \ldots \ldots$ & 60 & 3.0 & 24.0 & & & . \\
\hline June $13 \ldots \ldots \ldots \ldots \ldots$ & 55 & 2.9 & 19.6 & & & \\
\hline June $14 \ldots \ldots \ldots \ldots \ldots \ldots$ & 52 & 2.4 & 17.0 & & & \\
\hline June $17 \ldots \ldots \ldots \ldots \ldots$ & 24.5 & 1.8 & 19.8 & & & \\
\hline June $18 \ldots \ldots \ldots \ldots \ldots \ldots$ & 25.0 & 1.7 & 20.2 & 34.0 & 1.2 & \\
\hline June $19 \ldots \ldots \ldots \ldots \ldots$ & 29 & 1.5 & 22.0 & 46.0 & & \\
\hline June $21 \ldots \ldots \ldots \ldots \ldots$ & 31 & 1.9 & 18.4 & 43.0 & & \\
\hline June $22 \ldots \ldots \ldots \ldots \ldots \ldots$ & 31.0 & 1.7 & 14.2 & & 4.2 & \\
\hline June $23 \ldots \ldots \ldots \ldots \ldots \ldots$ & 28.0 & 1.5 & 9.8 & 40.0 & & \\
\hline June $25 \ldots \ldots \ldots \ldots \ldots \ldots$ & 28.4 & 1.4 & 7.7 & & & \\
\hline June $26 \ldots \ldots \ldots \ldots \ldots$ & 28 & 1.3 & 9.0 & & & \\
\hline June $26 \ldots \ldots \ldots \ldots \ldots$ & (Transfu & used $500 \mathrm{c}$ & c. citrated & d blood) & & \\
\hline June $27 \ldots \ldots$ & 36 & 2.1 & 7.6 & & & \\
\hline June $30 \ldots \ldots \ldots \ldots \ldots$ & 41 & 2.4 & 7.0 & 10.0 & & \\
\hline July $2 \ldots \ldots \ldots \ldots \ldots$ & & & & & 0.2 & \\
\hline July $4 \ldots \ldots \ldots \ldots \ldots \ldots$ & 48 & 2.3 & 4.4 & & & \\
\hline July $7 \ldots \ldots$ & 46 & 2.5 & 7.0 & 5.0 & & \\
\hline July 12 . & 46 & 2.3 & 8.5 & 1.0 & & \\
\hline July $19 \ldots \ldots \ldots \ldots$ & 72 & 3.9 & 9.7 & & & \\
\hline
\end{tabular}

Treatment with phenylhydrazine hydrochloride was instituted as is shown in table 2. As the patient seemed rather resistant to treatment, it was thought advisable to increase the drug gradually. The 
phenylhydrazine was stopped when the hemoglobin reached 101 per cent. Despite the cessation of treatment the blood continued to fall rapidly. With the decrease in the red count the patient became very weak and she suffered constantly from gastric distress. Because of her prostration and gastric distress the decision was made to transfuse her, following which procedure an improvement was noted within a short time. Her strength returned and the nausea and vomiting ceased. The red blood cell count slowly increased until she was discharged, when the blood picture was approaching normal.

Case II. G. W. A white American shoe inspector aged 63, entered the hospital September 21, 1924, complaining of a partial paralysis of the right side. His family and past history were unimportant. The patient stated that in 1921 his friends remarked about his "high color." He had felt very well until November, 1922, when he had a monoplegia of his left leg. He entered a hospital and remained there six weeks. He returned to work and remained in good health until May, 1923, when he had a right-sided hemiplegia. The patient entered a hospital and stayed there six months, during which period he suffered from severe headaches. He was told that he had "too much blood" and frequent venesections were performed with no relief. His hemiplegia improved and he was able to walk with the aid of crutches, but throughout the past year he has suffered from daily headaches.

The physical examination revealed a well nourished man, oriented in all respects. The skin of the face and hands had a beefy red hue. There were many small spider angiomata over the maxillary prominences. The conjunctivae and the mucous membranes of the mouth were injected. The tongue was not atrophic. The heart and lungs were normal. A moderate amount of smooth sclerosis was present in the radials, brachials, and temporals. Blood pressure-148/96. Residual findings of a right hemiplegia were present.

Laboratory data. Red blood cells-10,230,000. Hemoglobin (NewcomerHaldane)-122 per cent. White blood cells-18,300. The smear showed slight achromia. Reticulated red blood cells -0.8 per cent. Hematocrit -62 per cent. Blood bilirubin (Van den Bergh) $-0.3 \mathrm{mgm}$. per $100 \mathrm{cc}$. of blood plasma. The urine and stool were normal. Diagnosis: Polycythemia vera.

Inasmuch as the red blood cell count of this patient did not diminish under the original dosage it was deemed advisable to increase the amount of phenylhydrazine as is shown in table 3. This was done without producing any untoward events. The clinical condition of the patient improved from the beginning of his treatment. His headaches soon disappeared and he gradually became stronger. A 
TABLE 3

\begin{tabular}{|c|c|c|c|c|c|c|}
\hline Date & $\begin{array}{l}\text { Hemo- } \\
\text { globin }\end{array}$ & $\begin{array}{c}\text { Red } \\
\text { blood cells }\end{array}$ & $\begin{array}{l}\text { White } \\
\text { blood cells }\end{array}$ & $\begin{array}{c}\text { Reticulated } \\
\text { red cells }\end{array}$ & $\begin{array}{c}\text { Plasma } \\
\text { bilirubin }\end{array}$ & Drug \\
\hline & per cent & millions & thousands & per cent & mgm. & grams \\
\hline September $25 . \ldots \ldots \ldots \ldots$ & 122 & 10.2 & 18.3 & 0.8 & 0.3 & \\
\hline September $29 \ldots \ldots \ldots \ldots \ldots$ & 128 & 9.8 & 14.7 & & 10.4 & 0.1 \\
\hline September $30 \ldots \ldots \ldots \ldots$ & 133 & 10.0 & 17.5 & & & 0.1 \\
\hline October $1 \ldots \ldots \ldots \ldots \ldots$ & 124 & 9.7 & 17.4 & & & 0.1 \\
\hline October $2 \ldots \ldots \ldots \ldots \ldots$ & 118 & 9.6 & 15.8 & & & 0.1 \\
\hline October $3 \ldots \ldots \ldots \ldots \ldots$ & 118 & 9.8 & 16.8 & & & 0.1 \\
\hline October $4 \ldots \ldots \ldots \ldots \ldots$ & 120 & 9.8 & 18.0 & & & 0.1 \\
\hline October $5 \ldots \ldots \ldots \ldots \ldots$ & 118 & 10.0 & 17.1 & & & 0.1 \\
\hline October $6 \ldots \ldots \ldots \ldots \ldots$ & 116 & 9.4 & 15.1 & 1.4 & 0.8 & 0.1 \\
\hline October $7 \ldots \ldots \ldots \ldots \ldots$ & 125 & 10.0 & 12.4 & & $\cdot$ & 0.2 \\
\hline October $8 \ldots \ldots \ldots \ldots \ldots$ & 123 & 8.7 & 18.1 & & & 0.1 \\
\hline October $9 \ldots \ldots \ldots \ldots \ldots$ & 125 & 9.1 & 16.4 & & & 0.2 \\
\hline October $10 \ldots \ldots \ldots \ldots \ldots$ & 135 & 9.8 & 17.9 & & & 0.1 \\
\hline October $11 \ldots \ldots \ldots \ldots \ldots$ & 133 & 10.2 & 17.4 & & & 0.2 \\
\hline October $12 \ldots \ldots \ldots \ldots \ldots$ & 125 & 9.9 & 18.6 & & & 0.1 \\
\hline October $13 \ldots \ldots \ldots \ldots \ldots$ & 127 & 8.2 & 16.1 & & 0.7 & 0.2 \\
\hline October $14 \ldots \ldots \ldots \ldots \ldots$ & 125 & 8.7 & 15.3 & & & 0.1 \\
\hline October $15 \ldots \ldots \ldots \ldots \ldots$ & 125 & 8.9 & 26.2 & & & 0.2 \\
\hline October $16 \ldots \ldots \ldots \ldots \ldots$ & 125 & 8.4 & 21.3 & & & 0.2 \\
\hline October $17 \ldots \ldots \ldots \ldots \ldots$ & 127 & 9.0 & 20.8 & & & 0.2 \\
\hline October $18 \ldots \ldots \ldots \ldots \ldots$ & 116 & 9.4 & 21.8 & 1.4 & & 0.2 \\
\hline October $20 \ldots \ldots \ldots \ldots \ldots$ & 114 & 8.8 & 14.9 & & 0.9 & 0.2 \\
\hline October $21 \ldots \ldots \ldots \ldots \ldots$ & 122 & 9.7 & 20.4 & & & 0.2 \\
\hline October $22 \ldots \ldots \ldots \ldots \ldots \ldots$ & 122 & 9.0 & 16.4 & & & 0.2 \\
\hline October $23 \ldots \ldots \ldots \ldots \ldots$ & 122 & 9.1 & & & & - \\
\hline October $24 \ldots \ldots \ldots \ldots \ldots$ & 116 & 9.3 & 16.8 & & & \\
\hline October $25 \ldots \ldots \ldots \ldots \ldots$ & 116 & 7.9 & 20.4 & & 1.2 & \\
\hline October $27 \ldots \ldots \ldots \ldots \ldots$ & 111 & 7.9 & 17.6 & & 1.2 & \\
\hline October $28 \ldots \ldots \ldots \ldots \ldots$ & 114 & 8.6 & 24.4 & & & \\
\hline October $29 . \ldots \ldots \ldots \ldots \ldots$ & 108 & 8.4 & 25.0 & & & \\
\hline October $30 \ldots \ldots \ldots \ldots \ldots$ & 111 & 8.3 & 22.0 & . & & 0.4 \\
\hline October $31 \ldots \ldots \ldots \ldots \ldots$ & 108 & 8.2 & 23.0 & & & 0.4 \\
\hline November $3 . \ldots \ldots \ldots \ldots$ & 106 & 7.6 & 26.1 & 3.4 & 1.4 & \\
\hline November $4 \ldots . . \ldots \ldots$ & 106 & 7.3 & 24.1 & & · & \\
\hline November $5 \ldots . . \ldots \ldots \ldots$ & 102 & 7.1 & 20.6 & & & \\
\hline November $6 . . . \ldots \ldots \ldots$. & 106 & 7.0 & 21.9 & & & \\
\hline November $7 \ldots \ldots \ldots \ldots$ & 104 & 6.5 & 22.3 & & & \\
\hline November $8 \ldots \ldots \ldots \ldots$ & 102 & 6.0 & 26.9 & & & \\
\hline November $10 . \ldots \ldots \ldots \ldots$ & 101 & 5.9 & 24.0 & & 1.1 & \\
\hline November $11 \ldots \ldots \ldots \ldots$. & 97 & 5.9 & 24.5 & & & \\
\hline
\end{tabular}


phlebitis of the internal saphenous veins of both legs was the only incident during the whole period of treatment and this cleared up rapidly under symptomatic therapy.

The urine which was straw-colored prior to the administration of phenylhydrazine, soon developed a dark amber color and caused a moderate reduction of Benedict's Solution throughout the period of treatment. Urobilinogen was present from the third day until

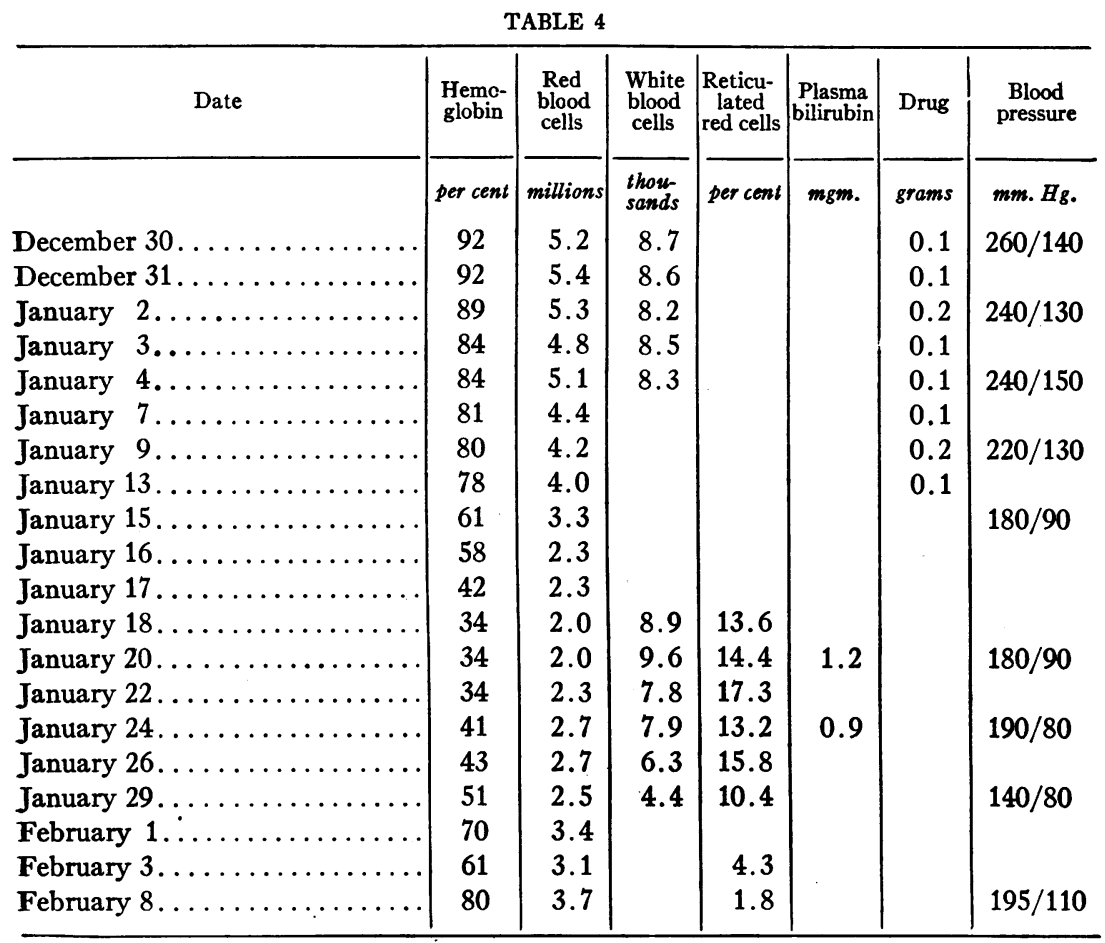

three weeks after the cessation of the drug. There was no albuminuria or hematuria at any time. Methemoglobin was found in the blood spectroscopically during treatment. This patient was discharged completely relieved of all symptoms in any way referable to his polycythemia.

The beneficial results obtained by Geisbock in a case of polycythemia hypertonica treated with phenylhydrazine hydrochloride led us to test the efficacy of the drug in a case of Essential Hypertension. 
Case III. M. S. A white American.housewife, aged 60, entered the hospital December 9, 1924, complaining of weakness in the left leg. Her mother and maternal grandmother died of apoplexy. For fifteen years previous to her entry she had been troubled with indigestion. One year before coming to the hospital a cholecystectomy was done. Four years before she had been told that she had "high blood pressure." She never had headaches. For a few months before entrance she had been troubled with nocturia and frequency. On December 4, 1924, her left leg became weak while walking, and on arising the next morning she found it impossible to use that leg. At that time she suffered from numbness in her left hand and arm. This weakness and numbness had practically disappeared before coming to the hospital.

The physical examination showed a well developed and well nourished woman. Except for the cardio-vascular system no important abnormalities were found in the examination. The heart was slightly enlarged, but the sounds were regular and of good quality. There were systolic murmurs at the apex and in the aortic area. The pulses were regular and equal. The radial and brachial arteries were moderately sclerosed and were easily palpable. Blood pressure-270/160. No definite residual signs of the hemiplegia could be detected.

Laboratory data. Red blood cells-5,250,000. Hemoglobin (Sahli)-92 per cent. White blood cells-7,600. The smear was normal. Blood bilirubin (Van den Bergh)—normal. The blood Wassermann was negative. The urine and stool were normal. Phenolsulphophthalein-45 per cent, in two hours. Diagnoses: Arteriosclerosis; hypertension.

As is shown in table 4, there was a marked change in the patient's blood pressure while under phenylhydrazine therapy. While there was a drop in both the systolic and diastolic pressures, it was believed that this might be attributed to the fact that the patient was very quiet during the period when the red blood count was low. It was interesting to note that during the period of anemia the patient insisted that she felt better than she had for months.

The urine was a dark amber color and contained urobilin. There was no albuminuria or hematuria at any time. Methemoglobin was determined in the patient's blood one week after phenylhydrazine was started. There were no irritating symptoms attending the use of the drug. A normal regeneration of the blood accompanied by the pouring out of reticulated cells and normoblasts took place. At times, myelocytes were present. When discharged the patient's blood had gradually returned to normal.

Case IV. P. M. A Russian laborer, aged 36, entered the hospital February 27,1925 , complaining of shortness of breath, weakness and headaches. His past 
and family history were unimportant. Three years before his entrance he noticed that he tired easily and a short time later nocturnal headaches. began to occur. His friends remarked upon the redness of his face and hands. He stopped work but the weakness and headaches became more pronounced, and he soon developed difficulty in getting his breath. He entered a hospital and from there was sent to a convalescent home for several months. His rest benefited him but as soon as he started to work, he again became very weak and short of breath. Once more he entered a hospital and was discharged in a few weeks unimproved. Shortly after this he came under our observation.

The physical examination showed a well developed and well nourished man lying in bed without any apparent discomfort. The skin of his face and hands was a dusky blue in color. His conjunctivae were injected and the mucous membranes of his mouth and lips were very cyanotic. There was no atrophy of the mucous membranes of the tongue. The thorax showed marked enlargement in the antero-posterior diameter and was typically barrel-shaped. His thorax moved as a whole during respiration and the respirations were slow and regular. There was no dyspnea. The lungs were hyperresonant to percussion. Tactile and vocal fremitus were normal. The breath sounds were emphysematous in type. The lower border of the lung descended $1.5 \mathrm{~cm}$. on full inspiration on the right side, and $2 \mathrm{~cm}$. on the left. The maximum impulse of the heart could be neither seen nor felt, and the area of cardiac dulness could not be made out. The sounds were distant, low and regular, and there were no murmurs. The pulses were equal, rhythmical, and of good tension. There was no peripheral arteriosclerosis. Blood pressure-122/84. The abdomen was normal. There was a suggestion of clubbing in the distal phalanges of the fingers. Fluoroscopy showed that the thorax moved little, if at all, during inspiration. Roentgenograms revealed that the heart was enlarged in the region of the left auricle and that the pulmonary artery was enlarged. The lungs showed emphysema in the lower lobes and few bronchial markings in the upper lobes. The electrocardiogram showed normal rhythm, P.R. -0.20 second, $\mathrm{P}_{2}-0.1$ millivolt, Q.R.S. -0.08 second. Axis normal. Variation in $\mathrm{S}_{3}$ and $\mathrm{T}_{3}$. The vital capacity was, sitting$3,100 \mathrm{cc}$; standing $-3,000 \mathrm{cc}$; lying $-2,550 \mathrm{cc}$.

Laboratory data. Red blood cell count-6,240,000. Hemoglobin (NewcomerHaldane)-120 per cent. White blood cells-7,400. The smear was normal. Reticulated red blood cells -0.2 per cent. Hematocrit 53 per cent. Blood bilirubin (Van den Bergh) $-0.4 \mathrm{mgm}$. per $100 \mathrm{cc}$. of blood plasma with a delayed direct diazo reaction. The Wassermann was negative. The sputum showed no turbercle bacilli. The urine and stool were normal. The phenolsulphophthalein test returned 50 per cent of the dye in 2 hours and 10 minutes. Basal metabolism (Aub-Dubois)-plus 3 per cent. Diagnosis: Emphysema with compensatory polycythemia or Ayerza's syndrome.

With this patient, it was a question as to whether the polycythemia was the primary condition. It was our desire to observe whether 
any beneficial effects would be obtained if the patient's blood picture was reduced to normal. Acetyl phenylhydrazine (pyrodin) was used because Bodansky (9) reported that it seemed to be the least toxic member of the phenylhydrazine series.

Table 5 shows that the hemoglobin and red count gradually declined under the influence of the drug. Daily differential white blood

TABLE 5

\begin{tabular}{|c|c|c|c|c|c|c|}
\hline Date & $\begin{array}{l}\text { Hemo- } \\
\text { globin }\end{array}$ & $\begin{array}{c}\text { Red } \\
\text { blood cells }\end{array}$ & $\begin{array}{l}\text { White } \\
\text { blood cells }\end{array}$ & $\begin{array}{l}\text { Reticulated } \\
\text { red cells }\end{array}$ & $\begin{array}{c}\text { Plasma } \\
\text { bilirubin }\end{array}$ & $\begin{array}{c}\text { Drugs } \\
\text { (pyrodin) }\end{array}$ \\
\hline & per cent & millions & thousands & per cent & mgm. & grams \\
\hline April $6 \ldots \ldots \ldots \ldots \ldots \ldots$ & 120 & 7.4 & 7.8 & 0.2 & 0.35 & 0.1 \\
\hline April $7 \ldots \ldots \ldots \ldots \ldots \ldots$ & 113 & 7.3 & 9.3 & 0.1 & & \\
\hline April $8 \ldots \ldots \ldots \ldots \ldots \ldots$ & 116 & 6.8 & 6.3 & & 0.33 & 0.1 \\
\hline April $9 \ldots \ldots \ldots \ldots \ldots \ldots$ & 104 & 6.2 & 6.0 & & & 0.1 \\
\hline April $10 \ldots \ldots \ldots \ldots \ldots \ldots$ & 102 & 6.4 & 10.1 & & & 0.1 \\
\hline April $11 \ldots \ldots \ldots \ldots \ldots \ldots$ & 92 & 6.2 & 7.1 & & & 0.1 \\
\hline April $13 \ldots \ldots \ldots \ldots \ldots \ldots$ & 84 & 5.2 & 7.2 & 0.2 & 0.5 & 0.2 \\
\hline April $14 \ldots \ldots \ldots \ldots \ldots \ldots$ & 85 & 6.2 & 9.5 & & & - \\
\hline April $15 . \ldots \ldots \ldots \ldots \ldots \ldots$ & 90 & 5.9 & 5.5 & & & 0.1 \\
\hline April $16 \ldots \ldots \ldots \ldots \ldots$ & 93 & 5.3 & 6.5 & & & 0.1 \\
\hline April $17 \ldots \ldots \ldots \ldots \ldots \ldots$ & 81 & 5.6 & 5.2 & & & 0.2 \\
\hline April $18 \ldots \ldots \ldots \ldots \ldots \ldots$ & 84 & 5.2 & 4.8 & & & 0.2 \\
\hline April $19 \ldots \ldots \ldots \ldots \ldots$ & 94 & 5.7 & 8.7 & & & 0.2 \\
\hline April $20 \ldots \ldots \ldots \ldots \ldots \ldots$ & 81 & 5.2 & 6.2 & & & \\
\hline April $21 \ldots \ldots \ldots \ldots$ & & 5.1 & 8.3 & 1.3 & & 0.2 \\
\hline April $22 \ldots \ldots \ldots \ldots \ldots$ & 80 & 4.5 & 5.5 & & & \\
\hline April $23 \ldots \ldots \ldots \ldots \ldots$ & 69 & 4.5 & 7.1 & & 0.9 & \\
\hline April $25 \ldots \ldots \ldots \ldots \ldots \ldots$ & 75 & 4.6 & 5.7 & & & \\
\hline April $27 \ldots \ldots \ldots \ldots \ldots$ & 72 & 4.3 & 8.5 & & & \\
\hline April $28 \ldots \ldots \ldots \ldots \ldots$ & 78 & 4.5 & 9.5 & 6.8 & & \\
\hline April $29 \ldots \ldots \ldots \ldots \ldots$ & 74 & 4.2 & 7.4 & & 1.1 & \\
\hline April $30 \ldots \ldots \ldots \ldots \ldots$ & 78 & 4.5 & 9.0 & & & \\
\hline $\operatorname{May} 1 \ldots \ldots \ldots \ldots \ldots$ & 79 & 4.2 & 9.1 & & & \\
\hline May $2 \ldots \ldots \ldots \ldots \ldots \ldots$ & 83 & 4.5 & 9.0 & & & \\
\hline May $4 \ldots \ldots \ldots \ldots \ldots \ldots$ & 89 & 4.0 & 9.0 & & & \\
\hline May $6 \ldots \ldots \ldots \ldots \ldots \ldots$ & 93 & 5.7 & 7.8 & 4.4 & 0.9 & \\
\hline May $13 \ldots \ldots \ldots \ldots \ldots \ldots$ & 85 & 4.5 & 7.4 & 0.8 & 0.7 & \\
\hline
\end{tabular}

counts were made using the vital technique as described by Sabin (10). It is interesting to note that on three successive days numerous monocytes with ingested red blood cells were observed. On one occasion a small clasmatocyte containing hemoglobiniferous particles was seen in the peripheral circulation. 
The urine partially reduced Benedict's Solution on the first day of the therapy and continued to do so until eleven days after the drug had been stopped. Urobilin appeared in the patient's urine upon the fourth day and was present in large amounts until the time of patient's discharge from the hospital. There was no hematuria or albuminuria at any time.

For the first few days the patient seemed to be benefited by the decrease in the hemoglobin content of the blood. He said that he felt stronger and that his headaches and shortness of breath were markedly relieved. This improvement continued until the hemoglobin dropped below 80 per cent, at which point the patient began to complain of great weakness, shortness of breath, nausea and vomiting, and headache. The drug had been discontinued two days before these distressing symptoms put in their appearance. Ten days later when the blood count and hemoglobin had increased, the patient made some improvement, but not enough to warrant the use of phenylhydrazine in this type of polycythemia.

One must be guided by the needs of the patient when using phenylhydrazine derivatives in the treatment of polycythemia. Experience in this hospital indicates the wisdom of using small doses of the drug in the beginning of the treatment. It seems wise to start with 0.1 gram per day by mouth and to continue this amount until the red blood count begins to fall or until one gram of the drug has been given. Then it seems well to discontinue the drug for three days and observe whether or not its cumulative action is marked. If there is no significant change in the blood picture the drug should be given again, alternating 0.1 gram and 0.2 gram doses until the desired results have been obtained or until another gram of phenylhydrazine has been administered. A week should pass before starting the third course of the drug if two grams do not bring about the desired results. The red blood cell count, hemoglobin and white blood cell count should be determined daily in order that any sudden change in the blood picture may be detected at once. By proceeding slowly it is possible to obtain the maximum therapeutic effect of phenylhydrazine with little danger to the patient.

Phenylhydrazine hydrochloride, when taken by mouth in capsules, did not cause irritation of the gastro-intestinal tract. It was ab- 
sorbed into. the blood and caused methemoglobin to be formed. This apparently injured the red blood cells and allowed them to be phagocytized and then destroyed. The white blood cells did not seem to be affected by the phenylhydrazine, as no leukocytosis referable to phenylhydrazine was noted. Any change in the white blood cells fell within the limits of the normal rhythm of the leukocytes (11). The differential white blood cell count remained normal under this treatment. The reticulated red blood cell count increased as the red blood cell count dropped. Occasionally normoblasts and myelocytes were seen if the blood dropped to a low level. The platelets remained normal. Phagocytosis of red blood cells in the peripheral blood stream occasionally was seen. Coincident with this phagocytosis the patients developed slight jaundice and the blood bilirubin was increased in amount and gave the delayed direct diazo reaction. The bilirubin content of the blood gradually declined after treatment was stopped, and after blood destruction ceased.

The color of the urine changed soon after the drug was administered, and assumed a deep amber color. The phenylhydrazines are reducing agents, and mild reducing substances have been noticed in the urine of the patients under treatment. Urobilinogen and urobilin appeared in the urine on the second or third day of treatment and continued to be present as long as blood destruction took place.

No evidence of kidney irritation has been observed in any of the patients who received phenylhydrazine hydrochloride. Apparently the drug had a moderate cumulative action, being slowly excreted in the urine. This cumulative action upon the blood was shown by the fact that the red blood cell count continued to fall for several days after the drug had been discontinued.

The best results with phenylhydrazine were achieved in the treatment of polycythemia vera. In this condition, with no discomfort to the patient, the blood can be reduced to normal and held there with ease for a considerable period of time. With a normal blood picture these patients lose the symptoms of their polycythemia and are greatly benefited. We have not seen any patient in whom we have detected any signs of liver damage arising from phenylhydrazine.

In our experience the drug was of little value in the treatment of secondary polycythemia or hypertension. 


\section{CONCLUSIONS}

Phenylhydrazine hydrochloride and acetyl phenylhydrazine are efficient therapeutic agents in the treatment of polycythemia vera.

\section{BIBLIOGRAPHY}

1. Renvers: Arb. a. d. erst. med. Klin. Zu. Berl., 1891, ii, 471. Ueber Pyrodin.

2. Morawitz, P., and Pratt, J.: Munch med. Wchnschr., 1908, lv, 1817. Einige Beobachtungen bei experimentellen Anamien.

3. Eppinger, H., and Kloss, K.: Therap. Monatsh., Berl., 1918, xxxii, 322. Zur Therapie der Polyzythamie.

4. Taschenberg, E. W.: Deutsche Med. Wchnschr., Berl., 1921, xlvii, 774. Ueber die Behandlung der Polyzythamie mit Phenylhydrazin.

5. Strassburger, J.: Therap. Halbmonatsh., 1921, xxxv, 777. Zur Behandlung der Polyzythamie.

6. Geisbock, F.: (Abstract Jour. Amer. Med. Ass., 1923, lxxxi, 258.)

7. Owen, T.: Bull. Johns Hopkins Hosp., 1924, xxxv, 258. A Case of Polycythemia Vera with Special Reference to the Familial Features and Treatment with Phenylhydrazine.

8. Levi, E.: Ztschr. f. klin. med. Berl., 1924, c, 777. Ueber die Ursache der Lebercirrhose bei Polycythamie. Leberschadigung durch Phenylhydrazintherapie.

9. Bodansky, M.: Jour. Biol. Chem., 1924, lviii, 799. The Action of Hydrazine and Some of Its Derivatives in Producing Liver Injury as Measured by the Effect of Levulose Tolerance.

10. Sabin, F. R.: Bull. Johns Hopkins Hosp., 1923, xxxiv, 277. Studies of Living Human Blood Cells.

11. Sabin, F. R., Cunningham, R. S., Doan, C. A., and Kindwall, J. A., Bull. Johns Hopkins Hosp., 1925, xxxvii, 14. The Normal Rhythm of the White Blood Cells. 